IZA DP No. 4361

Marital Violence and Women's Employment and

Property Status: Evidence from North Indian Villages

Manasi Bhattacharya

Arjun S. Bedi

Amrita Chhachhi

August 2009 


\title{
Marital Violence and Women's Employment and Property Status: Evidence from North Indian Villages
}

\author{
Manasi Bhattacharya \\ Uganda \\ Arjun S. Bedi \\ Institute of Social Studies, The Hague \\ and IZA \\ Amrita Chhachhi \\ Institute of Social Studies, The Hague
}

Discussion Paper No. 4361

August 2009

IZA

P.O. Box 7240

53072 Bonn

Germany

Phone: +49-228-3894-0

Fax: +49-228-3894-180

E-mail: iza@iza.org

\begin{abstract}
Any opinions expressed here are those of the author(s) and not those of IZA. Research published in this series may include views on policy, but the institute itself takes no institutional policy positions.

The Institute for the Study of Labor (IZA) in Bonn is a local and virtual international research center and a place of communication between science, politics and business. IZA is an independent nonprofit organization supported by Deutsche Post Foundation. The center is associated with the University of Bonn and offers a stimulating research environment through its international network, workshops and conferences, data service, project support, research visits and doctoral program. IZA engages in (i) original and internationally competitive research in all fields of labor economics, (ii) development of policy concepts, and (iii) dissemination of research results and concepts to the interested public.
\end{abstract}

IZA Discussion Papers often represent preliminary work and are circulated to encourage discussion. Citation of such a paper should account for its provisional character. A revised version may be available directly from the author. 
IZA Discussion Paper No. 4361

August 2009

\section{ABSTRACT}

\section{Marital Violence and Women's Employment and Property Status: Evidence from North Indian Villages}

Dominant development policy approaches recommend women's employment on the grounds that it facilitates their empowerment, which in turn is believed to be instrumental in enhancing women's well-being. However, empirical work on the relationship between women's employment status and their well-being as measured by freedom from marital violence yields an ambiguous picture. Motivated by this ambiguity, this paper draws on testimonies of men and women and data gathered from rural Uttar Pradesh, to examine the effect of women's employment and asset status as measured by their participation in paid work and their ownership of property, respectively, on spousal violence. Unlike the existing literature, we treat women's work status and violence as simultaneously determined and find that women's engagement in paid work and ownership of property, are associated with sharp reductions in marital violence.

JEL Classification: J12, J15, J16

Keywords: domestic violence, employment status, property ownership, India

Corresponding author:

Arjun S. Bedi

Institute of Social Studies (ISS)

Kortenaerkade 12

2518 AX Den Haag

The Netherlands

E-mail: bedi@iss.nl 


\section{Introduction}

Historical organization of public and private spaces naturally associates women with private sphere and domesticity, and thus home is perceived as a woman's domain. However, home is not a safe abode and around the world, women are subjected to spousal violence. Based on survey data, a recent multi-country study (Garcia-Moreno et al., 2006) pegs the incidence of intimate partner inflicted physical violence at between 15 and 71 percent.

Domestic violence is recognized as a violation of the basic rights of women, and freedom from such violence is an important aspect of women's welfare. Domestic violence has severe health (physical and psychological) and social consequences for women (WHO, 2002). Various studies have shown (Carrillo, 1992; Heise et al., 1994, Menon-Sen and Shiva Kumar, 2001; Morrison and Orlando, 1999; UNICEF, 2000) the large economic and social costs of domestic violence. Violence or even the threat of violence constrains the choices women make and restricts their participation in development, thus, preventing them from realizing their full potential (ICRW, 1999, 2000, 2002).

Empirical evidence on violence against women in India is available from various sources. For instance, the National Family Health Survey III (NFHS III) conducted in 2005-06 (IIPS and Macro International, 2007) reveals that about one in three married women in India have experienced physical violence. According to a nationwide survey conducted by the International Center for Women's Research, 52 per cent of women have suffered at least one incident of physical or psychological violence in their lifetime (ICRW, 2000).

Beyond the incidence of violence, there is a small but growing body of literature which uses information from various parts of India (and elsewhere) to examine the 
empirical link between domestic violence and various socio-economic attributes. One strand of the literature focuses on the link between domestic violence (women's welfare) and dowry. Examples include, Bloch and Rao (2002) and Srinivasan and Bedi (2007) for India, Naved and Persson (2005) for Bangladesh and Zhang and Chan (1999) for Taiwan. A second stand of the literature examines the links between domestic violence and women's involvement in income generating activities as captured by a woman's earnings and participation in paid employment, and between violence and women's ownership of economic assets (gold and property). Theoretically, the effect of a woman's intrahousehold economic status on violence is ambiguous. While an increase in household economic resources attributable to a woman may reduce economic stress and spousal violence, it may also introduce additional tension and struggle within a household. In an effort to maintain the status quo, the increased economic strength of a woman may be countered by an increase in violence. Consistent with this theoretical ambiguity, the existing empirical evidence on the link between a woman's involvement in income generating activities and violence is not clear-cut. ${ }^{1}$ In the Indian context, Rao's (1997) study on a community in Karnataka shows that a wife's income is associated with reduced lifetime violence. With regard to women's employment, Jejeebhoy (1998) finds that a woman's employment in wage work has no statistically significant impact on the probability of experiencing violence in Uttar Pradesh and Tamil Nadu, while based on NFHS II, Kishor and Johnson (2004) report that, as compared to non-working women, women being paid in cash were more likely to have experienced lifetime physical violence. In contrast, Panda and Agarwal (2005) report that in Kerala, women with

\footnotetext{
${ }^{1}$ In a recent survey of the link between marital violence and women's involvement in income generation in developing countries, Vyas and Watts (2008) report that women's involvement in such activities is generally associated with a higher lifetime history of physical violence, although in three of the twenty sites the authors reported a statistically significant protective association and in five there was no association. Based on studies from twenty two sites which examined the link between women's involvement in income generation in the past year, the authors report that five recorded a protective association, six recorded a greater risk, while the rest did not find any association.
} 
regular employment as compared to unemployed women, were far less likely to have ever experienced violence. Beyond employment status, Panda and Agarwal's innovative study (2005) uses women's ownership of property (land and house) to capture economic status and finds that women's ownership of property is associated with a sharp reduction in domestic violence.

The ambiguities in the link between women's economic status and intimate partner violence may be driven by the tension between the protective influence of higher economic contribution and the threat to the image of the male bread winner, as well as context-specific reasons. In addition, an empirical concern which has rarely been addressed is the endogeneity between a woman's economic status (employment, income) and violence. ${ }^{2}$ For instance, as is the key concern in the developed country literature (see Staggs and Riger, 2005; Tolman and Wang, 2005), violence may inhibit women's participation in employment or women who experience violence may be more likely to seek paid employment. If women who experience violence are more likely to seek paid employment, then estimates that do not account for the simultaneous determination of paid employment and domestic violence are likely to overestimate the effect of women's income/employment status on domestic violence and draw the misleading conclusion that women with higher earnings or those engaged in paid work are more likely to experience violence. $^{3}$

\footnotetext{
${ }^{2}$ Rao (1997) points out that, women's income and violence may be endogenously determined but is unable to correct for this possibility due to lack of instrumental variables. A notable exception is Gibson-Davies et al. (2005) who use data from the United States and present instrumental variable estimates of the effect of women's employment on domestic violence.

${ }^{3}$ Gibson-Davies et al. (2005) study of low-income women in the United States shows that estimates that do not account for the endogeneity between domestic violence and employment grossly overestimate the effect of women's employment status on abuse. Indeed, correcting for endogeneity leads to sharply different results and while probit estimates reveal a zero or positive relationship between employment and abuse, the instrumental variable probit estimates show that, for all types of violence, employment is associated with a reduction in violence of between 4 to 8 percentage points.
} 
Our paper belongs to the genre of work that examines the link between women's employment status and ownership of economic assets on domestic violence. In particular, based on qualitative and quantitative primary data collected from eight villages of Kaushambi district in Uttar Pradesh, a northern Indian state, this paper examines the link between women's participation in paid work and women's ownership of property on domestic violence. While there are other papers that have examined such links, this paper offers several relatively novel features. First, unlike other papers in this area which are usually based only on responses from females, this paper draws its insights from the testimonies of women and men. Information from both women and men allows us to compare the reasons both sexes provide for the use of violence and allows us to gauge the extent to which violence may be under-reported. Second, in our empirical work we attempt to control for the potentially endogenous relationship between women's engagement in paid work and spousal violence. Third, while there are a number of papers that have examined the link between women's income/employment and violence, the link between women's ownership of land and property is restricted to Panda and Agarwal (2005). Their paper on the effect of women's ownership of property on violence is based on Kerala, a South Indian state where a substantial proportion of the population follows a matrilineal system and where women enjoy relatively more autonomy and freedom of movement, as compared to the North. In contrast, this paper examines whether the violence-reducing effects of property ownership also prevail in a North Indian state which has a strong patrilineal system and where women enjoy relatively less autonomy.

The following section of the paper provides a brief description of the study area and the data. Section III provides a discussion of female employment patterns and spousal violence in the study area and discusses the relationship between women's 
employment and asset status and spousal violence. Section IV outlines the empirical specification. Section V discusses the econometric estimates and section VI concludes.

\section{The context and the data}

The paper is based on information from Kaushambi, a relatively less developed district in Uttar Pradesh (henceforth UP), a northern state of India. According to Census 2001 data, Kaushambi has a high degree of illiteracy (70 percent amongst women and 38 percent amongst men, as compared to corresponding state-level averages of 58 percent and 31 percent, respectively), and a high infant mortality rate (100 per 1000 live births as compared to the state-level figure of 87 per 1000 live births).

Hindus constitute the majority of the state's population (about 85 percent) and the social order in the state is based on the caste system amongst the Hindus. As in other north Indian states, gender relations are driven by patriarchal socio-cultural norms which are, as noted by Agarwal (1988, p.92), 'characterized by lower female labour participation (and higher gender disparities in participation), a higher incidence of dowry, greater intra-household discrimination against female children, and lower female (to male) survival chances than the southern states'.

Empirical confirmation of the nature of gender disparities comes from various sources. For instance, 2001 census figures show that at 43 percent, female literacy rate in the state is considerably lower than average female literacy rate (65 percent) in the four Southern states (Andhra Pradesh, Kerala, Karnataka, Tamil Nadu). Similarly, female labour force participation rate is 29 percent in Uttar Pradesh as compared to 45 percent in the Southern states (Planning Commission, 2002). Dowry differences across regions also reflect the asymmetric gender relations and a recent study by Dalmia and Lawrence (2005) reports that dowries are twenty eight per cent higher in Uttar Pradesh (north India) than in Karnataka (south India). The lower chances of female survival are reflected in the 
state's population sex ratio of 898 females per 1000 males which may be compared to the average population sex ratio of 997 in the four Southern states (Census of India, 2001).

\section{II.B The data}

The data used in this paper were collected in 2006 and the data collection process was designed to deal with two issues. First, to examine the role of women's economic status (as captured by their participation in paid employment and ownership of assets) on their mobility, freedom from violence and their decision-making domain and the effect of women's work participation on the health of their children (in the age group 0-5). Given these aims, Kaushambi district was chosen as it has a relatively high rate of female work participation as compared to the rest of the state. ${ }^{4}$ In order to explore caste and class variations within Kaushambi district, data was gathered from eight multi-religious and multi-caste villages.

A variety of data collection methods was used. At the district level, key informants included the District Magistrate (head of the district administration) and the Chief Medical Officer, who were interviewed to gather background information on the district, while village level information on characteristics such as number of households, occupational pattern, presence of physical infrastructure, education and health facilities was collected by interviewing village leaders, Anganwadi workers (workers in charge of the village child care centre) and teachers. Eight focus group discussions were conducted to elicit information about familial norms, intra-household decision making, access to and control over resources, and their daily routine. In addition to these discussions, five life stories of women from different age/caste groups were documented, which threw light on intra-household dynamics, changes in socio-economic and cultural patterns.

\footnotetext{
${ }^{4}$ According to data from Census 2001, the rate of female work participation rate in rural Kaushambi is 31 percent versus 19 percent in rural Uttar Pradesh.
} 
At the household level, a semi-structured survey was fielded in 155 households, that is, about 20 households from each of the eight villages. ${ }^{5}$ Given the aims of the study, the target population was defined as complete pair households, that is, both husband and wife are alive and living in the same physical space, with at least one child in the age group 0 to 5 . Households satisfying these criteria were further sub-divided into those in which women participated regularly in paid work (that is, women who worked more than 6 months during the year) and those in which women did not engage regularly in paid work. About half the respondents were randomly chosen from each of these two groups. At the household level both husbands and wives were canvassed. The survey gathered a wide range of information on issues such as educational and employment status, economic status and ownership of assets, intra-household allocation of resources, household violence, income and income sharing patterns, mobility and decision making.

Given the purposive manner in which the sample data have been gathered (focusing on an area with a relatively higher rate of female work participation and on complete pair households with a young child), it should be clear that our aim is not to generalize our findings for women in the state or even the district, but to examine whether in the particular context of a poor North Indian rural setting characterized by a patrilineal system and relatively low status of women, whether the economic status of women has a bearing on their welfare. ${ }^{6}$

\section{Female employment status and domestic violence}

\footnotetext{
${ }^{5}$ The econometric work reported in the paper relies on a relatively small data set of 155 households. This is not large but is not unusually small. Recently published studies such as Bloch and Rao (2002) and Srinivasan and Bedi (2007) rely on about 137 to 142 households.. While the small size has its disadvantages, it also has the advantage of allowing coverage of a wide range of topics and the collection of reliable information on sensitive issues.

${ }^{6}$ In other words the paper is concerned with internal validity - that is attempting to isolate the causal effect of women's economic status on spousal violence - and not with generalization or external validity.
} 
This section provides an analytical narrative designed to aid the specification of our econometric model and help interpret estimates. Based on discussions with men and women, their remarks during focus group discussions, life-histories of key respondents and responses to structured questionnaires, this section provides an account of female employment status, characterizes domestic violence and subsequently explores the expected effects of several socio-economic variables of interest on the incidence of violence.

\section{III.A Female employment and attitude towards working women}

Consistent with the research design, as displayed in Table 1, about half the women in the sample are engaged in paid work. About 43 percent are working regularly as agricultural labourers (at least 6 months of the year) while six percent are engaged in non-agricultural occupations. On average, women in the sample account for about 17 percent of household income. Conditional on being engaged in paid work, the contribution of women to household income jumps to about 35 percent.

The survey contained a number of questions designed to explore the factors motivating women's participation in paid labour, and the attitudes of their husbands and other family members regarding their work participation. Female work patterns differ remarkably across castes, with work participation rates varying from 83 percent amongst the lower castes to only 26 percent amongst women belonging to the general caste group. Amongst Hindu lower castes and Muslim households, women's work force participation is poverty-driven and women reported that children's well-being was the primary motivation driving their decision to seek paid employment. Given their lack of assets and the limited earning capabilities of their husbands, they reported that they had no choice but to work. The general sentiment may be captured by a statement made by a female lower-caste agricultural wage labourer, 
If we do not work who will feed our kids?

A majority, about $76 \%$, of husbands (87\% if wife worked and $65 \%$ if wife was not working) supported work participation of their wives and pointed out that the main benefit was that their economic contribution would allow them to share household expenses and reduce the burden on husbands. ${ }^{7}$ For example, according to the husband of a lower-caste agricultural wage labourer,

Her earning contributes to family income and she can also fulfill some of her wishes, which I am not able to fulfill.

A similar sentiment comes from the husband of an upper-caste woman engaged in a nonagricultural government job,

She is in a government job, so if my business does not run well she will be able to support the family with her stable income. She will be able to bring up our kids in a better manner.

Support and recognition of the contribution of women's work extended beyond husbands. In joint families, in general, mother-in-laws approved of their daughter-inlaws' employment outside the family farm. Some mother-in-laws had themselves worked as wage labourers, while some were still working and the general perception was that women's work force participation would help the family in its daily battle for survival, contribute to family well-being and allow women to be independent and earn respect in society. For instance, commenting on her daughter-in-law's work participation, an uppercaste mother-in-law commented,

She can provide economic support to her family. She does not have to ask for money from anyone and it will increase her self-confidence.

For a few husbands the economic contribution of their wives was not important, and they felt that women should work as they need to be occupied. As a husband of a lower-caste wage labourer commented,

\footnotetext{
${ }^{7}$ The responses were remarkably similar across caste groups with support for work participation ranging from 72 to 78 percent across caste groups.
} 
Women waste their time on idle gossip and quarreling with each other. So they should utilize their time and earn some money.

While the overall impression gathered from the focus groups, conversations and responses to the structured questions was that women's economic contribution is valued, responses from the focus group discussion to questions on the effect of women's work on their status were not as positive. According to a lower caste unemployed husband,

Women's participation in low wage work does not improve their self-worth, as they earn a paltry sum and their income does not make any change in their intrahousehold status.

Working women's self-perception varied across caste/class. Upper caste women engaged in service sector (who also belonged to the economically better-off households) felt that their economic contribution was acknowledged within the family and it gave them self-respect and respect from family and community. ${ }^{8}$ However, among the lower castes, women asserted that their work did not improve their worth. According to a lower-caste wage labourer,

We women do not have any worth irrespective of the fact whether we earn or not. We are loved only at night by our husbands, and we do not have right to say 'no'. We always have to listen to our husbands.

While a majority of husbands recognized and valued the work contribution of their wives, a majority (about $76 \%$ ) pointed out that there were disadvantages. Specifically, amongst husbands expressing reservations, 60\% pointed out that women's work participation would affect the upbringing of children and their physical and cognitive development. ${ }^{9}$ Other concerns were the negative health consequences (tiredness) of work on their wives, which would reduce their ability to carry out household chores and compel their husbands to contribute to household work.

\footnotetext{
${ }^{8}$ Only 3 of them were working.

${ }^{9}$ Except for the general caste group which expressed a higher rate (about 77 percent) of concern about the effect of women's work participation on the welfare of children the rest of the caste/religion groups expressed a similar rate of reservation (between 56 and 60 percent).
} 
To summarize, women's work participation rates differ sharply across caste groups with extremely high rates of participation amongst lower caste groups and relatively lower rates of participation amongst the general caste. The figures in Table 1 and the comments made by women support the idea that women's work participation is driven mainly by economic imperatives and concerns for their children. Across all caste groups, there seems to be support for female work participation and female work appears to be valued, while at the same time there are concerns the impact of their work on their ability to look after children and discharge household responsibilities.

\section{III.B Domestic violence - A characterization}

There is no universally accepted definition of domestic violence. The boundaries of the relationship between the perpetrator and the abused, the norms of acceptable behaviour and specific acts constituting violence are crucial elements in defining domestic violence. ${ }^{10}$ In this paper we restrict ourselves to the incidence of inter-spousal physical violence that has taken place anytime during the course of a marriage. ${ }^{11}$

The information collected from the study villages shows that while there are instances of other family members inflicting violence on the respondent (wife), the husband is the primary assailant. Based on the responses of wives, 52 percent of them have experienced physical violence during the course of their marriage. ${ }^{12}$ In terms of husbands' responses, while fewer men were willing to respond to this question, about 59

\footnotetext{
${ }^{10}$ See ICRW (1999) for a discussion on definitional issues.

${ }^{11}$ Physical violence includes acts such as slapping, beating, arm-twisting, stabbing, strangling, kicking, burning. A focus on physical violence excludes emotional violence and is likely to underestimate the extent of total violence (emotional and physical). Data from NFHS III (IIPS and Macro International, 2007) shows that while this is indeed the case the extent of the underestimate is not large. For example, lifetime incidence of physical/sexual violence is about 37.2 percent. The inclusion of emotional violence increases this figure to 39.7 percent. This underestimate of about 3 percentage points remains the same across wealth classes, levels of female education, and caste.

${ }^{12}$ This figure may be compared with the 38 percent lifetime physical violence incidence rate reported in Uttar Pradesh based on NFHS III (IIPS and Macro International, 2007). This figure is somewhat lower than the figure found in the current sample but may partially be explained by the focus of this paper on women who are married while the NFHS III data pertain to all women in the age range 15-49.
} 
percent of those who did respond mentioned that they had beaten their wives. There is a high degree of consistency in the responses of husbands and wives and both provide the same response in 78 percent of the cases. Assuming that both husbands and wives have a tendency to underreport violence, the figures in Tables 3 and 4 suggest that men are far more likely to underreport as compared to women. In 16 out of 44 cases men who indicated using no violence are contradicted by their wives while only 8 of 65 women contradict their husband's claims of using violence. While there is underreporting, the consistent responses across men and women and the fairly limited degree of the underreporting supports the idea that these data on a sensitive issue such as domestic violence are not unduly influenced by measurement error.

The survey and discussions reveal that there are a variety of factors that trigger physical violence and there are sharp differences in the motives for inflicting violence as reported by husbands and wives (see Table 5). As far as husbands are concerned, the most common reason for using violence appears to be a need to discipline women if they challenge male authority and/or if they do not perform tasks as expected. About 73 percent of husbands admitted using violence when women were "disobedient," that is, when women questioned or objected to their behaviour (gambling, drinking), did not follow their instructions, and confronted mother-in-laws. About 46 percent of husbands used violence when household tasks were not properly performed by their wives (for example, food was not cooked properly and on time, clothes were not washed or children were not taken care of) and 11 percent mentioned the use of violence when women crossed a "private boundary" - by talking to other women, not observing purdah or meeting relatives without a husband's permission.

While a similar percentage of women (46 percent) support the idea that violence in the form of punishment for neglecting housework triggers violence, the responses 
provided by women provide a different picture of the reasons for violence. The key differences are the larger proportion of women who point out that violence (and drinking) is used by men as a way of releasing stress, anger and frustration. According to about 30 percent of the women, men's failure as a provider and their injured masculinity fuels violence and that wife beating is an outlet for the economic and social stress that they experience.

In the sample, the use of violence was justified by about half the women (50 percent) and a majority of men (80 percent). While female justification of wife-beating is not unusual in the Indian context, the interesting aspect of these numbers is that the percentage is 'only' about 50 percent. This figure may be contrasted with a justification rate of 74\% amongst a sample of women from Uttar Pradesh in 1993-94 as reported in Jejeebhoy (1998). While half the women mentioned that violence was justified at times and under certain circumstances, a similar percentage vociferously condemned the practice. For example, lower-caste women in one of the villages publicly expressed strong views against violence, used abusive language against men and mentioned that it was a pity that despite their valuable economic contribution, men beat them up.

Overall, while men resort to violence as a means of controlling women and as a pedagogical tool to discipline them for various transgressions, women viewed violence as an outlet for male stress and as a burden that they need to bear as part of marriage responsibilities.

\section{III.C Domestic violence and socio-economic correlates}

Drawing on the characterization provided above, the following sub-section provides a discussion of the expected effects of the main variables of interest on the incidence of violence. 


\section{Income and employment}

Based on the idea of economic stress as a source of violence it may be expected that an expansion of household economic resources, for example, due to an increase in income or an increase in land holding should ease economic stress and in turn reduce violence. In particular, since agricultural land is the key income generating asset in the village, an increase in access to land should be associated with a decline in violence. While an increase in overall economic resources should relieve the stress experienced by a husband, the source of the increased resources probably plays a key role in determining the relative welfare of the members of the household. An increase in the economic resources of the household, attributable to the husband, may unambiguously be expected to reduce economic stress and in turn to a reduction in violence. A husband's improved employment prospects should exert a similar effect. In contrast, an increase in household economic resources attributable to the wife may be expected to have an ambiguous effect on violence. While an increase in earnings reduces economic stress it may also introduce additional tension and struggle within the household. In an effort to extract and control the increased income and to counter the threat to the image of the male bread winner a man may resort to violence.

Thus, unlike the divorce-threat models presented by Farmer and Tiefenthaler (1997) and Zhang and Chan (1999) which predict that an increase in a woman's income unambiguously decreases the level of violence/increases welfare in intact marriages through its effect on raising her threat point or the separate-spheres bargaining models presented by Lundberg and Pollack (1993) and Suen, Chan and Zhang (2003) which show that even when divorce is not an option an increase in a woman's income increases

her welfare, our characterization of violence combined with the context under scrutiny suggests that the effect will be ambiguous. 
The divorce-threat models are unlikely to apply in the current context. In much of rural India it is not easy for a woman to leave a marriage. Even if a woman can support herself financially and live on her own, leaving a husband is likely to invite strong social disapproval. Whitehead in her study (1981:109) on the conjugal contract points out that 'the relative power of husbands and wives does not simply reflect relative wages commanded in the labour market'. Regardless of their employment and income prospects, familial ideologies about roles and responsibilities, of society's expectations, may often lead women to continue in a marriage. Kabeer (2000, p. 52) notes that, when the ideology of 'togetherness' is the primary organizing principle in a society, women invest time and energy to keep their marriage alive, seeking separation only in extreme circumstances. This view is corroborated by a female lower-caste woman engaged as a wage labourer who mentioned that though she did not approve of her husband's act of beating, she never thought of leaving him, as "only chinnals (characterless) women leave their husbands". Apart from the social stigma of divorce, even if credible, the need for male protection may also prevent women from exiting a marriage. Men's traditional role as a "protector" is still likely to prevail in the current context, even if women engaged in paid work do not need them as "providers".

Even if divorce is not an option, as in the separates-spheres bargaining models, and an increase in a woman's earnings increases her welfare in terms of increased consumption and leads to a "clearer perception of her individuality and well being" (Sen 1990, p. 144), this may not always translate into reduced violence. ${ }^{13}$ Given the use of violence as a way of retaining control it is quite possible that an increase in consumption induced by an increase in women's income is accompanied by additional control-induced

\footnotetext{
${ }^{13}$ Sen (1990) argues that "Outside earnings can give the woman in question a better breakdown position, possibly a clearer perception of her individuality and well being and a higher 'perceived contribution' to the family's economic position." This argument may still hold without necessarily translating into reduced violence.
} 
violence. This is similar to the possibly ambiguous effects of income on violence as proposed by Tauchen et al. (1991). Based on a non-cooperative family model Tauchen et al. (1991) point out that, if a man's marginal utility of violence were increasing with a woman's consumption then he may allow her greater consumption but also inflict more violence, as her income increases.

Overall, leaving a marriage is unlikely to present a credible threat to a husband and while the additional earnings capacity of a woman may expand the consumption possibilities of the wife and the household it may also invite additional violence

Thus, the effect of an increase in a woman's earnings and an improvement in her employment prospects are likely to have an ambiguous effect on violence.

\section{Wealth and education}

Paralleling the discussion above, while an expansion of household wealth in the form of greater ownership of gold and ownership of a dwelling should reduce economic stress and violence, the ownership of such assets probably plays a key role in determining relative welfare of the husband and wife. An increase in assets which are owned by a husband and under his control may unambiguously be expected to lead to a reduction in violence. An increase in assets owned by a wife, while reducing household economic stress, may have an ambiguous effect on violence. While ownership of an asset such as a house may provide a credible exit option from a marriage (as argued by Panda and Agarwal, 2005), and provide a shield for women, it may induce additional control-fuelled marital violence. ${ }^{14}$

The predicted effects of education on domestic violence are similar to the differential patterns expected for an increase in the incomes of the husband and wife. While an increase in husband's education through its effect on income and reinforced

\footnotetext{
${ }^{14}$ Panda and Agarwal (2005) argue that it is not an issue of whether women actually use the exit option that ownership of property provides, but that the existence of such an option may be expected to deter marital violence.
} 
through its effect on his social standing may be expected to reduce violence, the effect of women's education on violence may be ambiguous. To the extent that a woman's education is associated with an increase in income it should reduce violence. However, her education and awareness may also be a source of social stress for the man as it may challenge the traditional male image. In order to assert his authority, he may resort to violence.

Overall, for both economic flows (income and employment) and assets/endowments (wealth and education), while increases attributable to the husband may be expected to reduce violence, the effect of increased income and assets attributable to women will have an ambiguous effect on violence and will be an outcome of the tension between the reduced intra-household economic stress which works towards reducing violence and the potential increases in control-induced violence (social stress).

\section{Excessive alcohol consumption}

A number of women pointed out the link between alcohol and violence. In response to questions on the reasons for violence, several respondents mentioned that their husbands resort to violence when they are drunk. It is likely that the same observed and unobserved factors that create economic and social stress and lead a man to inflict violence are likely to drive excessive alcohol consumption. This suggests that drunkenness should not be treated as an exogenous variable but as an outcome of the same factors that may drive a man's violent actions. This view is corroborated by extensive reviews of the literature. These reviews confirm a strong association between excessive alcohol consumption and violence but point out that alcohol typically triggers violent behavior mainly in interaction with a number of other factors, ranging from socioeconomic, cultural to psychological and biochemical. These reports conclude that while 
alcohol abuse may spark violent behavior and serve as a catalyst, it is a symptom and not a cause of aggressive behaviour (The Amsterdam Group Report 2001). ${ }^{15}$

To summarize, on the basis of the discussion presented here it may be expected that women in households with larger economic resources experience less violence. An increase in employment, income and assets of a man are likely to reduce violence, while increases in the employment, income and assets of a woman may have an ambiguous effect on violence.

\section{Empirical Specification}

The hypotheses outlined above are testable and this section outlines a framework to subject our expectations to empirical scrutiny. Let $V$, a dichotomous variable, denote the presence of physical violence in the household. Based on the discussion in the preceding section, $V$ may be treated as a function of variables capturing the overall economic position of the household $\left(X_{E}\right)$, a husband's socio-economic characteristics $\left(X_{H}\right)$, a wife's socio-economic characteristics $\left(X_{W}\right)$, and a vector of additional explanatory variables $\left(X_{O}\right)$. Thus, violence may be represented as,

$$
V=X_{E} \beta_{E}+X_{H} \beta_{H}+X_{W} \beta_{V}+X_{O} \beta_{O}+\mathcal{\varepsilon} .
$$

The $\beta s$ are coefficients to be estimated and $\varepsilon$ represents unobservable factors which may influence violence. Based on the assumption that $\varepsilon$ follows a normal distribution this equation may be estimated using a probit model.

\footnotetext{
${ }^{15}$ A report prepared by The Social Issues Research Centre (1998) reaches a similar conclusion, "From the research evidence available, we can conclude that there is no direct causal relationship between alcohol and violence. Where the immediate social context is non-aggressive and where cultural beliefs and norms inhibit aggression, drinkers are highly unlikely to become aggressive".
} 
In operational terms, $V$ captures the incidence of inter-spousal physical violence.

The overall economic position of the household is captured by the amount of land owned by a household, the quality of their house (kuchha-weak or pucca-strong), and the amount of gold owned by the household. The husband's socio-economic characteristics include his occupation (self-employed in agriculture, agricultural wage labour, employed in nonagricultural activities), annual income, years of education, age and whether he drinks. The wife's characteristics include whether she is involved in paid work (wage labourer, non-agricultural activities), her annual income, years of education, age, and whether she owns the family house. Other variables included in the specification indicate number of male and female children, caste, religion and type of marital family (joint or nuclear). We estimate several variants of (1) to examine the sensitivity of the key economic status variables (women's employment status and house ownership) to changes in model specification.

A key concern is the potential endogeneity between a woman's working status and violence. It is possible that unobserved factors such as her ability and aspirations, which may motivate violence may also influence a women's working status. In other words, violence and working status maybe simultaneously determined and women who experience violence may be driven by the violence to seek work. These possibilities suggest that in equation (1), work status may be positively correlated with the error term and single-equation estimates of the effect of work status on violence may be upward biased reflecting the effect that women experiencing more violence are more likely to work. To tackle this issue we use two strategies. First, we control for a number of observed variables which are likely to influence both violence and women's work participation. To the extent that women's work participation and violence are driven by observed characteristics such as household economic assets and husband's employment 
status, inclusion of such controls should reduce the extent of the upward bias in the female employment status variables. Second, and more formally, we endogenize woman's work status and estimate a simultaneous two-equation violence and work status model. Specifically, woman's work status (that is engaged in paid outside the home) denoted by $\left(W_{w}\right)$ is treated as a function of a vector of explanatory variables $\left(X_{2}\right)$, that is,

$$
W_{w}=X_{2} \boldsymbol{\delta}+\boldsymbol{v}
$$

The vector $X_{2}$ contains several variables that overlap with the variables in (1) but it also contains variables that determine work status but are assumed not to have a bearing on violence (excluded from the violence equation). Assuming that the error term in (2) is normally distributed, equations (1) and (2) are simultaneously estimated using a bivariate probit model.

While model estimation is straightforward, a key issue in such procedures is identification and the validity of exclusion restrictions. In the current case, there are some natural and potentially very strong candidates that may serve as instruments. For instance, caste captures a family's economic and social standing and as may be expected is a crucial variable in determining work status. The caste of a family should be strongly correlated with work status but should have no bearing on violence, after controlling for the economic resources of a household. ${ }^{16}$ Additionally, as pointed out in Section IIIA, presence of young children and type and size of family are likely to influence women's work participation but may not have a direct bearing on violence. In our empirical work we estimate specifications using various combinations of caste indicators, number of

\footnotetext{
${ }^{16}$ Support for this idea comes from various sources. In particular, a number of ICRW $(1999,2000,2002)$ studies explore the links between caste and domestic violence. ICRW's study on Rajasthan reports that there is "no significant variation with respect to the caste of the respondent". Similarly, ICRW's Tamil Nadu study finds that 43 percent of non-Dalit men have inflicted physical violence as compared to 45 percent among Dalit men. Srinivasan and Bedi's (2007) study on Tamil Nadu also reports that there is no link between caste and violence after controlling for household economic status. As will be discussed later, in our case we find that after controlling for household economic resources, caste variables do not exert a statistically significant impact on violence.
} 
male and female children and type of family as instruments and test the validity and strength of our instruments.

\section{Empirical analysis}

\section{A. Descriptive statistics}

Descriptive statistics for the independent variables are provided in Table 6. Some of the salient features of these data are discussed below. The average land holding is 3.95 bighas or about one-fourth of an acre, which is quite small, and about 37 percent of households do not own any land. Although husbands are typically more educated than wives (6 years versus 3 years) the average education level is quite low. About 68 percent of women are illiterate while the corresponding figure for men is 34 percent. As may be expected, given the target population, the average couple is the sample is relatively young with a mean age of 32 for men and 28 for women. About $9 \%$ of the women report that they own the house in which the family lives. While female ownership of property is limited, given the North Indian context, it is not unexpected. In fact compared with the 16 percent female house ownership rate in rural Kerala (Panda and Agarwal, 2005) the figure here may not seem too low. The average number of children per household is three and a half with an equal proportion of boys and girls. About 23 percent of the men consume alcohol. While this may not appear to be alarming, it should not be interpreted as benign social drinking but as an indicator that a man drinks excessively. ${ }^{17}$

\section{B. Domestic violence and selected characteristics}

As a preview to the econometric work, Table 7 shows the bivariate relationship between domestic violence and some selected characteristics. The numbers clearly show that domestic violence is less likely to occur in better-off households. Households

\footnotetext{
${ }^{17}$ In the current context, drinking alcohol may be viewed as synonymous with excessive drinking. Rao (1997) makes a similar point and reports that $75 \%$ of men do not consume any alcohol but "those who do tend to consume a great deal".
} 
experiencing domestic violence have smaller land holdings (2.21 as compared to 5.87 bighas) and are less likely to live in pucca houses

(14.8 versus 31 percent). The education levels of the husband and wife have similar effects on domestic violence supporting the idea that better-educated households are less likely to experience violence. While, neither husband's or wife's income appear to be correlated with violence, there are sharp differences in the incidence of violence across husband's occupation. Husbands who are agricultural wage labourers (those with lowest incomes) are far more likely to inflict violence while working as a self-employed farmer (highest income category) is negatively associated with violence.

A wife's engagement in wage work appears to be associated with increased violence. The incidence of paid work amongst women experiencing violence is 56 percent as compared to 42 percent amongst those free of violence. While the higher incidence of violence amongst working women should not be construed as the effect of work on violence, as women from poorer households and those experiencing more violence are more likely to work, the correlation presented here highlights the importance of controlling for variables that influence female work participation (endogenizing work participation) as in the absence of such controls there may be a tendency to draw misleading conclusions. In any case, it is interesting to note that consistent with the literature from other developing countries, as reviewed in Vyas and Watts (2008), the bivariate analysis presented here is consistent with their conclusion that, in general, women's access to income is associated with a higher lifetime history of physical violence. In contrast to the effect of women's work status, a wife's ownership of a house is associated with a sharp reduction in violence. Female household ownership is about 16 percent amongst those who do not experience violence as compared to two percent amongst those who do. 


\section{Single equation probit estimates}

Table 8 presents estimates of several probit specifications of the violence equation. Following the narrative provided in the earlier sections, the discussion focuses on the role of household economic resources, and the socio-economic characteristics of the husband and wife in influencing the probability of experiencing violence.

We begin with what may be termed a "canonical" specification (Table 8, specification 1), variants of which have been estimated in other studies on domestic violence (for example, see Aekplakorn and Kongsakon, 2007; Flake, 2005; Jejeebhoy, 1998; Hindin and Adair, 2002; Naved and Persson, 2005; Rao, 1997). ${ }^{18}$ The common feature of this specification is that it does not control for husband's occupational status which, as will be discussed later, is a key variable driving the decision of a wife to seek work and also influences violence. Based on this specification we may draw the conclusion that there is no association between a woman's work status and violence. The interesting aspect here is that although not precisely estimated, the coefficient indicates that controlling for household economic resources, women's work is negatively correlated with violence. This may be compared with the bivariate table (Table 7) which shows a positive link between women's work and violence. The differences across tables highlights the importance of controlling for variables that are likely to have an effect on violence and women's work participation before assessing the effect of women's work on violence.

Table 8, specification 2, includes controls for the occupational status of husbands and as is displayed in the table there is a sharp change in the coefficient on women's

\footnotetext{
${ }^{18}$ While there are wide variations in the specifications that are estimated across these papers, their common characteristic (as in the specification presented in Table 8, spec. 1) is that they do not control for husband's occupational status. Hindin and Adair (2002) control for husband's employment status (works for pay or not) but given that 92 percent of the husbands in their sample work, this is not a very informative variable. Papers that do attempt to account for husband's job quality/occupation include Panda and Agarwal (2005) who control for husband's type of employment (regular and seasonal employment) while Kishor and Johnson (2004) control for husband's occupational status (agriculture or non-agriculture).
} 
work status. The effect is now statistically significant at conventional levels and the coefficient indicates that women engaged in paid work outside the household are about 22 percentage points less likely to experience violence as compared to women who do not work or work on the family farm. The sharp change in the absolute value of the coefficient indicates that in the absence of controls for husband's occupational status the coefficient on women's work status will be upward biased (more positive than it should be) and may lead to the misleading conclusion that there is a positive link between violence and work. To probe the effect of female work we split the work status variable into three different categories, that is working outside the home as an agricultural labourer, working in non-agricultural occupations and working on the family farm. As the estimates (Table 8, specification 3 to 5) show, the protective effect of women's employment on violence, a reduction of between 24 to 29 percentage points, comes mainly from women working as agricultural wage labourers (regular employment for at least 6 months a year). The effect of working in non-agricultural activities is not statistically significant, probably due to the small number of women engaged in such work. The interesting aspect is that working on the family farm does not offer any protection and women whose main activity is working on the family farm are likely to experience as much violence as non-working women.

As far as the other key variable of interest - female property ownership - is concerned, consistent with the findings of Panda and Agarwal (2005), there is a clear link between women's ownership of property and violence. Across all specifications, women's ownership of property is associated with a 33 to 36 percentage point reduction in violence. This is a large effect and supports the idea that the protective effect of female property ownership is not restricted to the particular case of Kerala but also works towards dissuading violence in a North Indian context. 
Turning briefly to the other variables we see that consistent with the bulk of the literature the amount of land owned by a household is negatively linked to violence but the effect is not statistically significant. Similarly, the estimates show that families residing in a pucca as opposed to a kuccha house are 17 to 25 percentage points less likely to experience violence, but the effect is not very precisely measured. The effect of husband's occupation (an indicator of household income) is large and shows that husbands who are self-employed in agriculture (the highest income category) are 32 to 37 percentage points less likely to inflict violence as compared to husbands involved in nonagricultural occupations. ${ }^{19}$ Overall, the results support the idea that violence is less likely to occur amongst higher income and wealthier households.

Consistent with expectations, a husband's education works towards reducing violence. The estimated effect reflects the correlation between education and income which reduces economic stress and the status-conferring effect of education which reduces social stress. A one-year increase in a man's education is associated with a 2.5 to 2.9 percentage point reduction in violence. While a woman's education also exerts a negative effect, it is not statistically significant. ${ }^{20}$

The number of sons, daughters and type of family are not associated with violence. In section IV, we argued that after controlling for household economic resources, caste should not have a bearing on domestic violence. To examine this empirically, Table 8, specification 6 includes a set of caste and religion dummies. The

\footnotetext{
${ }^{19}$ We prefer to use occupational status indicators to capture household income as these variables are less likely to be plagued by measurement error as compared to the income information. Nevertheless, we estimate specifications which do control for the income of the husband and wife (Table A1, spec. 2). The inclusion of these measures does not alter the effect of women's work status and ownership of property.

${ }^{20}$ Rao (1993) and Zhang and Chan (1999) estimate specifications where women's welfare, are treated as functions of educational and age differences between husband and wife. As pointed out by Edlund (2000) such specifications impose the restriction that the attributes of husband and wife influence women's welfare in a symmetric manner. This may not be and is certainly not the case in our data and hence we treat violence as a function of individual traits rather than differences.
} 
caste variables (other backward castes and scheduled castes) do not exert an effect on violence. The religion dummy is also statistically insignificant at conventional levels (although the $p$-value is close to 10 percent). Jointly the set of variables that capture family composition, family type and caste are jointly statistically insignificant ( $p$-values ranging from 0.30 to 0.35 ).

Finally, while alcohol consumption certainly appears to trigger violence (see Table 7), as argued earlier, it is likely that unobserved factors (e.g., work pressure, temperament) that lead to drunken behaviour are correlated with domestic violence and domestic violence and alcohol consumption are endogenous. Nevertheless, in the spirit of conducting a sensitivity analysis we include an indicator of the drinking habits of husbands in our estimated models (Table A1, specification 3). As may be expected there is a large and statistically significant effect of drinking on violence. However, regardless of the inclusion of this variable, the magnitude of the coefficient on work status and women's ownership of property, remains in the same range as observed in our baseline specifications (2 and 3 in Table 8).

\section{Simultaneous equation probit estimates}

Despite the stability of the effect of female work status on violence and the inclusion of a number of controls that determine women's work participation and violence, it is possible that there are unobserved characteristics that affect female work status and violence. For example, women who are more motivated and have higher economic aspirations may be more likely to seek work and these qualities may also encourage violence. In such circumstances single equation probit estimates may underestimate the protective effect of women's employment status. To account for the effect of such unobserved common traits, equation (1) and (2) are estimated simultaneously. Maximum likelihood estimates of bivariate probit models are presented 
in columns 1 to 4 of Table 9, while instrumental variable regression estimates (that is, estimating equations 1 and 2 using OLS) are presented in columns 5 and 6. Although not entirely appropriate, as the dependent variables are discrete, we use an instrumental variables model as this approach allows us to apply specifications tests to examine the strength and validity of the instruments.

Estimates of the work status equation (2) are presented in columns 1, 3 and 5 of the table while the remaining columns present marginal effects of the probability of domestic violence. The work status equation presented in column 1 is identified on the basis of family composition and type while estimates in columns 3 and 5 are identified on the basis of family composition, family type and caste variables. ${ }^{21}$ On the basis of previous literature and knowledge of the context we argued that while caste should play an important role in determining women's work status, after controlling for household economic resources, it should not have a bearing on violence. The estimates in Table 9 (columns 3 and 5) show that belonging to a scheduled caste sharply increases the probability of working while as shown earlier, caste does not have an influence on domestic violence (see Table 8, column 6). Formal statistical tests show that the instruments are correlated with a woman's work status. An F-test for excluding the instruments records a $p$-value 0.065 and the partial $R$-squared of the excluded instruments is 0.083 . To examine the validity of the instruments we carried out a test for overidentifying restrictions. The test statistic recorded a p-value of 0.419 , that is, the test does not reject the null hypothesis of no correlation between some of the instruments and the error term in the violence equation. ${ }^{22}$

\footnotetext{
${ }^{21}$ We also estimated an additional bivariate probit specification which relied only on the caste variables to achieve identification. The estimates were in the same range as reported in Table 9.

${ }^{22}$ Instrumental variables estimates based on the caste variables to achieve identification are presented in Table A1, columns 4 and 5. These estimates are similar to those reported in Table 9.
} 
Turning to the estimates themselves, a glance shows that for the most part, they are not sensitive to the variable set used for identification nor to the method of estimation. The estimates display that husband's occupation, education and caste have statistically significant and large effects on a woman's work status. Women whose husbands are engaged as wage labourers are between 44 to 63 percentage points more likely to seek paid work as compared to women whose husbands are engaged in non-agricultural activities, while, women whose husbands are self-employed in agriculture are about 17 to 24 percentage points less likely to be engaged in paid work as compared to those whose husbands are engaged in non-agricultural activities. Husband's education is also negatively linked to women's work status and the wives of more educated men less likely to work (the marginal effect ranges between 1.6 and 3.8 percentage points). These estimates are consistent with the reasons that women provide for seeking work (Section II) and support the idea that female work participation is driven by the limited economic opportunities faced by their husbands. The caste variable picks up similar patterns, in the sense that work participation is about 27 to 37 percentage points more likely amongst scheduled caste households. This reflects the constrained economic circumstances of such households but also the greater social acceptability of work amongst such families as compared to the general castes.

We now turn to the violence equation (columns 2, 4 and 6). First, regardless of the variable set used for identification and the method of estimation, the estimates are quite stable. Second, although there are changes in the magnitude of the coefficients, the overall story emerging from the simultaneous equation estimates is not very different from the single-equation estimates. Husband's education continues to be associated with a reduction in violence and husband's engaged in more remunerative occupations are less likely to use violence. The effect of women's ownership of property lies in the same 
range as the single-equation estimates, it remains statistically significant and continues to exert a protective effect. The effect of a woman's work status also exerts a protective effect but is much larger as compared to the single equation estimates. These estimates indicate that women engaged in regular paid work outside the household are 62 to 64 percentage points less likely to experience violence as compared to non-working women. The jump in the magnitude of this coefficient supports the idea that it is important to account for the simultaneous determination of violence and women's work participation. While a doubling of the coefficient may seem large it is not unusual. For example, in their study of low-income women in the United States, Gibson-Davies et al. (2005) show that estimates that do not account for the endogeneity between domestic violence and employment grossly overestimate the effect of women's employment status on abuse. According to their estimates, single-equation probit estimates reveal a zero or even a positive relationship between employment and abuse, while their instrumental variable probit estimates show that for all types of violence, employment is associated with a reduction in violence of between 4 to 8 percentage points (that is, an infinite increase in the magnitude of the employment status coefficients between the single and simultaneous equation estimates). The sharp increases in the simultaneous equation estimates supports the idea that at the very least, based on the single-equation estimates, women's engagement in regular paid agricultural work (as compared to women who do not work for wages or are self-employed on the family farm) reduces the incidence of violence by 24 to 29 percentage points.

\section{Concluding remarks}

On the basis of a micro-level village study this paper explored the link between the effect of women's ownership of their household dwelling and the effect of their regular employment (at least 6 months of the year) in paid work on intra-spousal 
violence. A notable feature of the empirical work presented in the paper is that it controlled for the potentially endogenous relationship between women's engagement in paid work and spousal violence.

The study showed that women's employment in regular paid work has a large effect on reducing violence. The effect of women's work status reflects the tension between the reduction of violence which may be generated by the effect of her work on increasing the economic resources of the household and the increases in violence which may be generated due to challenges to a husband's authority and masculinity (social stress). In the case under investigation it seems clear that the enhanced economic resources generated by the work contribution of a woman works towards reducing intrahousehold violence. Whether her work contribution also leads to greater mobility and enhances her intra-household decision-making locus still needs to be thoroughly investigated..$^{23}$ Methodologically, this paper showed that it is important to treat female work status and violence as simultaneously determined. Estimates that do not account for the possibility that violence may motivate a woman to seek work, are more likely to draw the misleading conclusion that women's work status does not provide any protection but is indeed associated with an increased incidence of violence.

Beyond women's work status, across all specifications we found that women's ownership of property has a large effect on reducing violence. This is similar to the effect reported by Panda and Agarwal (2005) in the Kerala context. A similar finding in a very different context suggests the wider implications of female ownership of property and lends support to their view that women's ownership of property increases a woman's economic security, reduces her willingness to tolerate violence and by providing a credible exit option works towards deterring spousal violence.

${ }^{23}$ Preliminary investigations reported in Bhattacharyya (2006) suggest that this may not be the case. 
Overall, the results presented in this paper suggest that women's access to income-generating opportunities and control over assets play a key role in reducing their vulnerability to violence. Policies which encourage income-generation and greater involvement of women in regular paid work outside their homes and help women build and retain control over assets are necessary in order to increase their security. 


\section{References}

Aekplakorn W., R. Kongsakon (2007) Intimate partner violence among women in slum communities in Bangkok, Thailand. Singapore Medical Journal 48(8): 763-768.

The Amsterdam Group Report (2001) http://www.efrd.org/events pub/docs/TagReport2001.pdf accessed on 24 April 2006).

Bhattacharyya, M. (2006) Women's employment versus child well-being: Contradictory outcomes? MA Thesis. The Hague: Institute of Social Studies.

Bloch, Francis and V. Rao (2002) Terror as a Bargaining Instrument: A Case Study of Dowry Violence in Rural India, American Economic Review 92(4): 1029- 1044.

Carrillo, R. (1992) Battered dreams: Violence against women as an obstacle to development. New York: United Nations Development Fund for Women.

Dalmia, S. and P.G. Lawrence (2005) The Institution of Dowry in India: Why It Continues To Prevail, The Journal of Developing Areas 38(2):71-93.

Edlund, Lena (2000) The marriage squeeze interpretation of dowry inflation: A comment, Journal of Political Economy 108(6): 1327-1335.

Farmer, Amy and Jill Tiefenthaler (1997) An economic analysis of domestic violence, Review of Social Economy 55(3): 337-358.

Flake D.F. (2005) Individual, family and community risk factors for domestic violence in Peru. Violence Against Women 11(3): 353-373.

Garcia-Moreno C., H.A. Jansen, M. Ellsberg, L. Heise, C.H. Watts (2006) Prevalence of intimate partner violence: findings from the WHO multi-country study on women's health and domestic violence, Lancet 368(9543): 1260-1269.

Gibson-Davis, C, K. Magnuson, L.A. Gennetian, G.J. Duncan, Employment and the Risk of Domestic Abuse Among Low-Income Women, Journal of Marriage and Family, 67(5):1149-1168

Heise, L.L., J.Pitanguy and A.Germain (1994) Violence against women: The hidden health burden, World Bank Discussion Paper 255. Washington, DC: World Bank.

Hindin M.J. and L.S. Adair (2002) Who's at risk? Factors associated with intimate partner violence in the Philippines, Social Science and Medicine 55(8): 1385-1399.

ICRW (1999) Domestic violence in India. A summary report of three studies. Washington, DC: International Center for Research on Women.

ICRW (2000) Domestic violence in India. A summary report of a multi-site household survey. Washington, D.C.: International Center for Research on Women.

ICRW (2002) Men, masculinity and domestic violence in India. Summary report of four studies. Washington, DC: International Center for Research on Women.

IIPS and Macro International (2007) National Family Health Survey (NFHS-3),2005-06, India, Vol. II, Mumbai: International Institute for Population Sciences 
Jejeebhoy, S.J. (1998) Wife-beating in rural India: A husband's right? Economic and Political Weekly 33(15):855-862.

Kabeer, N. (2000) Resources, Agency, Achievements: Reflections on the Measurement of Women's Empowerment in Sahara Razavi (ed.) Gendered Poverty and Well-Being, pp.27-56. Oxford: Blackwell.

Kishor, S. and K. Johnson (2004) Profiling Domestic Violence: A Multi-Country Study. MACRO International: Calverton, MD.

Lundberg S. and R.A. Pollak (1993) Separate spheres bargaining and the marriage market, Journal of Political Economy 101 (6): 988-1010.

Menon-Sen, Kalyani and A.K.Shiva Kumar (2001) Women in India: How free? How equal? New Delhi: Office of the United Nations Resident Coordinator in India.

Morrison, A.R. and M. Orlando (1999) Social and economic costs of domestic violence: Chile and Nicaragua, in A.R. Morrison and L. Biehl (eds.), Too close to home: Domestic Violence in the Americas, pp. 51-80. Washington, DC: IADB.

Naved R.T. and L.A. Persson (2005) Factors associated with spousal physical violence against women in Bangladesh. Studies in Family Planning 36(4): 289-300.

Panda, Pradeep and Bina Agarwal (2005) Marital violence, human development and women's property status in India' World Development 33(5): 823-850.

Planning Commission, Government of India (2002) National Human Development Report 2001. http://planningcommission.nic.in/reports/genrep/nhdrep/nhdreportf.htm.

Rao, Vijayendra (1997) Wife-beating in rural South India: A qualitative and econometric analysis, Social Science and Medicine 44 (8): 1169-1180.

Rivers, D. and Q. Vuong (1988) Limited information estimators and exogeneity tests for simultaneous probit models, Journal of Econometrics 39(3): 347-366.

Sen, Amartya (1990) Gender and co-operative conflicts, in I. Tinker (ed.) Persistent inequalities: Women and world development, pp.123-145. Oxford: Oxford University Press

Social Issues Research Centre (1998) http://www.sirc.org/publik/drinking_contents.html (accessed on 24 April 2006).

Simister, J. and Makowiec, J., (2008) Domestic Violence in India: Effects of Education, Indian Journal of Gender Studies 15 (3):507-518.

Srinivasan, S. and A.S. Bedi (2007) Domestic violence and dowry: Evidence from a South Indian village, World Development, 35 (5): 857-880.

Staggs, S.L., and S. Riger (2005). Effects of intimate partner violence on low-income women's health and employment. American Journal of Community Psychology, 36(1/2): 133-144.

Suen, Wing, William Chan and Junsen Zhang (2003) Marital transfer and intra-household allocation: A Nash-bargaining analysis, Journal of Economic Behavior and Organization 52(1): 133-146.

Tauchen, Helen, Ann Dryden Witte and Sharon Long (1991) Domestic Violence: A Nonrandom Affair, International Economic Review 32(2): 491-511. 
Tolman, R.M. and H. Wang (2005) Domestic violence and women's employment: fixed effects models of three waves of women's employment study data. American Journal of Community Psychology 36(1/2): 147-158.

UNICEF (2000) Domestic violence against women and girls, Innocenti Digest (6). Florence: UNICEF Innocenti Research Centre.

Visaria, L (2000) Violence against Women: A Field Study, Economic \& Political Weekly 35 (20):1742-51.

Visaria, L. (2008) Violence against Women in India: Is Empowerment a Protective Factor? Economic \& Political Weekly 43(48): 60-66.

Vyas, S. and C. Watts (2008) How does Economic Empowerment Affect Women's Risk of Intimate Partner Violence in Low and Middle Income Countries? A Systematic Review of Published Evidence, Journal of International Development. DOI: 10.1002/jid.1500.

Whitehead, Ann (1981) 'I'm hungry, mum': The politics of domestic budgeting in Kate Young, Carol Wolkwitz and Rosyln McCullagh (eds.) Of marriage and the market: Women's subordination in international perspective, pp. 88-111. London: CSE books.

WHO (2002) World report on violence and heath. Geneva: WHO.

Zhang, Junsen and William Chan (1999) Dowry and Wife's Welfare: A Theoretical and Empirical Analysis, Journal of Political Economy 107(4): 786-808 
Table 1

Male and Female Main Activity Status (\%) [absolute numbers]

\begin{tabular}{|c|c|c|c|c|}
\hline & \multicolumn{2}{|c|}{ Male } & \multicolumn{2}{|c|}{ Female } \\
\hline & $\begin{array}{c}\text { Main } \\
\text { Activity }\end{array}$ & $\begin{array}{l}\text { Annual } \\
\text { Income } \\
\text { (std. dev.) } \\
\end{array}$ & $\begin{array}{c}\text { Main } \\
\text { Activity }\end{array}$ & $\begin{array}{l}\text { Annual } \\
\text { Income }\end{array}$ \\
\hline Work on own/leased farm & $\begin{array}{l}14.2 \\
{[22]}\end{array}$ & $\begin{array}{c}30,036 \\
(74,058)\end{array}$ & $\begin{array}{l}14.2 \\
{[22]}\end{array}$ & $\begin{array}{c}2,040 \\
(4,692)\end{array}$ \\
\hline Agricultural Wage Labourer & $\begin{array}{l}52.3 \\
{[81]}\end{array}$ & $\begin{array}{l}12,157 \\
(6,220)\end{array}$ & $\begin{array}{l}43.2 \\
{[67]}\end{array}$ & $\begin{array}{c}4,790 \\
(2,342)\end{array}$ \\
\hline $\begin{array}{l}\text { Non-agricultural occupations } \\
\text { (own business, nurse, sewing, } \\
\text { mason, carpenter) }\end{array}$ & $\begin{array}{l}30.9 \\
{[48]}\end{array}$ & $\begin{array}{c}23,509 \\
(18,815)\end{array}$ & $\begin{array}{l}6.45 \\
{[10]}\end{array}$ & $\begin{array}{c}14,040 \\
(11,285)\end{array}$ \\
\hline Does not participate & $\begin{array}{l}2.6 \\
{[4]}\end{array}$ & . & $\begin{array}{l}36.1 \\
{[56]}\end{array}$ & . \\
\hline
\end{tabular}

Table 2

Female Activity Status by Caste/Religion (\%) [absolute numbers]

\begin{tabular}{|l|c|c|c|c|}
\hline & $\begin{array}{c}\text { Hindu- } \\
\text { General }\end{array}$ & $\begin{array}{c}\text { Hindu- } \\
\text { OBC }\end{array}$ & $\begin{array}{c}\text { Hindu- } \\
\text { SC }\end{array}$ & Muslim \\
\hline Work on own/leased farm & 10 & 30 & 5 & 13 \\
& {$[3]$} & {$[13]$} & {$[3]$} & {$[3]$} \\
\hline Agricultural Wage Labourer & 0 & 33 & 74 & 44 \\
& {$[0]$} & {$[14]$} & {$[43]$} & {$[10]$} \\
\hline $\begin{array}{l}\text { Non-agricultural occupations } \\
\text { (own business, nurse, sewing, } \\
\text { mason, carpenter) }\end{array}$ & {$[5]$} & {$[1]$} & 3 & 9 \\
\hline Does not participate & 74 & 35 & 17 & {$[2]$} \\
& {$[23]$} & {$[15]$} & {$[10]$} & {$[8]$} \\
\hline
\end{tabular}

Table 3

Incidence of physical violence (\%) [absolute numbers]

\begin{tabular}{|c|c|c|}
\hline & Reported by wives & Reported by husbands \\
\hline & 52.3 & 59.6 \\
& {$[81]$} & {$[65]$} \\
\hline$N$ & 155 & 109 \\
\hline
\end{tabular}

Table 4

Incidence of physical violence (\% of total) [absolute numbers]

\begin{tabular}{|c|c|c|c|}
\hline & \multicolumn{2}{|c|}{ Reported by husbands } & \\
\hline Reported by wives & Yes & No & $N$ \\
\hline Yes & $\begin{array}{l}52.3 \\
{[57]}\end{array}$ & $\begin{array}{l}14.7 \\
{[16]}\end{array}$ & 73 \\
\hline No & $\begin{array}{c}7.34 \\
{[8]}\end{array}$ & $\begin{array}{l}25.7 \\
{[28]}\end{array}$ & 36 \\
\hline$N$ & 65 & 44 & 109 \\
\hline
\end{tabular}


Table 5

Reasons for wife-beating (\%)

\begin{tabular}{|l|c|c|}
\hline & $\begin{array}{c}\text { Reported by } \\
\text { husbands }\end{array}$ & $\begin{array}{c}\text { Reported by } \\
\text { wives }\end{array}$ \\
\hline Disobedience & 73.2 & 20.8 \\
\hline Neglecting housework & 46.4 & 45.7 \\
\hline Crossing the private sphere & 11.2 & 5.0 \\
\hline $\begin{array}{l}\text { Release for husband's } \\
\text { frustration/tension/anger }\end{array}$ & 0.0 & 14.8 \\
\hline $\begin{array}{l}\text { Release tension/anger under } \\
\text { the influence of alcohol }\end{array}$ & 2.8 & 16.0 \\
\hline Without any reason & 0.0 & 13.6 \\
\hline Infidelity & 0.0 & 2.5 \\
\hline$N$ & 71 & 81 \\
\hline
\end{tabular}

Note: Based on multiple responses

Table 6

Descriptive Statistics

\begin{tabular}{|l|c|c|}
\hline \multicolumn{1}{|c|}{ Variable } & Mean & Std. Dev. \\
\hline Land owned by household (in bighas) & 3.95 & 12.8 \\
Condition of house - pucca & 0.23 & 0.42 \\
Condition of house - kuccha-pucca & 0.22 & 0.42 \\
Quantity of gold (in grams) & 4.95 & 12.11 \\
& & \\
Husband's education (in years) & 6.39 & 5.40 \\
Husband's age & 32.3 & 6.01 \\
Husband's annual income in Rupees & 17,905 & 30,441 \\
Husband drinks = & 0.23 & 0.42 \\
& & \\
Wife's education (in years) & 2.89 & 4.67 \\
Wife's annual income in Rupees & 2879 & 4260 \\
Wife's age & 28.27 & 5.26 \\
Wife owns house & 0.09 & 0.29 \\
& & \\
Number of living sons & 1.70 & 1.18 \\
Number of living daughters & 1.82 & 1.45 \\
Nuclear family = 1 & 0.73 & 0.45 \\
& & \\
Hindu - General = 1 & 0.20 & 0.40 \\
Hindu - Other Backward Castes =1 & 0.28 & 0.45 \\
Hindu - Scheduled Caste =1 & 0.37 & 0.49 \\
Muslims = 1 & 0.15 & 0.36 \\
\hline
\end{tabular}

Notes: The number of observations is 155 except for the variable indicating husband's drinking habits where $N=125$ 
Table 7

Domestic Violence and Selected Characteristics

\begin{tabular}{|l|c|c|c|}
\hline \multicolumn{1}{|c|}{ Variable } & DV $=0$ & DV $=1$ & $p$-value \\
\hline Land owned by household (in bighas) & 5.87 & 2.21 & 0.075 \\
Condition of house - pucca & 0.310 & 0.148 & 0.015 \\
& & & \\
Husband's education (in years) & 8.31 & 4.62 & 0.000 \\
Husband's age & 30.8 & 33.6 & 0.000 \\
Husband's main activity-agricultural wage labourer & 0.391 & 0.642 & 0.001 \\
Husband's main activity-self-employed in agriculture & 0.230 & 0.061 & 0.002 \\
Husband's annual income in Rupees & 22077 & 14095 & 0.119 \\
Husband drinks = & 0.09 & 0.35 & 0.000 \\
& & & \\
Wife's education (in years) & 4.24 & 1.65 & 0.000 \\
Wife's age & 27 & 30 & 0.000 \\
Wife's annual income in Rupees & 2593 & 3141 & 0.431 \\
Wife engaged in paid work outside home & 0.42 & 0.56 & 0.090 \\
Wife owns house & 0.162 & 0.024 & 0.000 \\
& & & \\
Number of living sons & 1.59 & 1.80 & 0.276 \\
Number of living daughters & 1.42 & 2.18 & 0.000 \\
Family type: Nuclear & 0.64 & 0.81 & 0.155 \\
& & & \\
Hindu - General = 1 & 0.28 & 0.12 & 0.013 \\
Hindu - Other Backward Castes =1 & 0.27 & 0.28 & 0.851 \\
Hindu - Scheduled Caste =1 & 0.40 & 0.34 & 0.446 \\
Muslims = 1 & 0.04 & 0.25 & 0.000 \\
\hline
\end{tabular}

Notes: The last column of the table reports p-values for a two-tail t-test. The null hypothesis is equality of means. The number of observations is 155 except for the variable indicating husband's drinking habits where $N=125$ 
Table 8

Probability of Experiencing Violence - Probit Estimates

(Absolute value of T-statistic)

\begin{tabular}{|c|c|c|c|c|c|}
\hline Variable & $\begin{array}{c}\text { Marginal } \\
\text { Effects } \\
\text { Spec.1 }\end{array}$ & $\begin{array}{c}\text { Marginal } \\
\text { Effects } \\
\text { Spec. } 2\end{array}$ & $\begin{array}{c}\text { Marginal } \\
\text { Effects } \\
\text { Spec.3 }\end{array}$ & $\begin{array}{c}\text { Marginal } \\
\text { Effects } \\
\text { Spec.4 }\end{array}$ & $\begin{array}{c}\text { Marginal } \\
\text { Effects } \\
\text { Spec.5 }\end{array}$ \\
\hline Land owned by household & $\begin{array}{l}-0.004 \\
(1.14)\end{array}$ & $\begin{array}{c}-0.0008 \\
(0.24)\end{array}$ & $\begin{array}{c}-0.0011 \\
(0.31)\end{array}$ & $\begin{array}{c}-0.0012 \\
(0.35)\end{array}$ & $\begin{array}{c}-0.0006 \\
(0.16)\end{array}$ \\
\hline Condition of house - pucca & $\begin{array}{l}-0.171 \\
(1.42)\end{array}$ & $\begin{array}{r}-0.194 \\
(161)\end{array}$ & $\begin{array}{l}-0.206 \\
(1.63)\end{array}$ & $\begin{array}{c}-0.249^{*} \\
(196)\end{array}$ & $\begin{array}{c}-0.218^{*} \\
(166)\end{array}$ \\
\hline Condition of house - kuccha-pucca & $\begin{array}{l}0.052 \\
(0.45)\end{array}$ & $\begin{array}{l}0.011 \\
(0.08)\end{array}$ & $\begin{array}{l}0.013 \\
(0.11)\end{array}$ & $\begin{array}{l}0.019 \\
(0.15)\end{array}$ & $\begin{array}{c}.019 \\
(0.15)\end{array}$ \\
\hline Amount of gold in household & $\begin{array}{l}0.005 \\
(1.14)\end{array}$ & $\begin{array}{l}0.002 \\
(0.51)\end{array}$ & $\begin{array}{l}0.003 \\
(0.59)\end{array}$ & $\begin{array}{l}0.002 \\
(0.47)\end{array}$ & $\begin{array}{l}0.002 \\
(0.52)\end{array}$ \\
\hline Husband's education & $\begin{array}{c}-0.025^{*} \\
(2.35)\end{array}$ & $\begin{array}{c}-0.028^{*} \\
(2.66)\end{array}$ & $\begin{array}{c}-0.029 * \\
(2.68)\end{array}$ & $\begin{array}{c}-0.028^{*} \\
(2.44)\end{array}$ & $\begin{array}{c}-0.026^{*} \\
(2.23)\end{array}$ \\
\hline Husband's age & $\begin{array}{l}-0.027 \\
(1.29)\end{array}$ & $\begin{array}{l}-0.025 \\
(1.16)\end{array}$ & $\begin{array}{l}-0.024 \\
(1.10)\end{array}$ & $\begin{array}{l}-0.027 \\
(1.30)\end{array}$ & $\begin{array}{l}-0.023 \\
(1.09)\end{array}$ \\
\hline Husband's occupation - agri. wage labourer & . & $\begin{array}{l}0.025 \\
(0.15)\end{array}$ & $\begin{array}{l}0.021 \\
(0.15)\end{array}$ & $\begin{array}{l}0.034 \\
(0.24)\end{array}$ & $\begin{array}{l}0.008 \\
(0.05)\end{array}$ \\
\hline Husband's occupation - agri. self-employed & . & $\begin{array}{c}-0.338^{*} \\
(2.27)\end{array}$ & $\begin{array}{c}-0.321^{*} \\
(1.77)\end{array}$ & $\begin{array}{c}-0.326^{*} \\
(1.77)\end{array}$ & $\begin{array}{c}-0.372 * \\
(2.02)\end{array}$ \\
\hline Wife's education & $\begin{array}{c}-0.021^{*} \\
(1.71)\end{array}$ & $\begin{array}{l}-0.015 \\
(1.22)\end{array}$ & $\begin{array}{l}-0.022 \\
(1.58)\end{array}$ & $\begin{array}{l}-0.019 \\
(1.35)\end{array}$ & $\begin{array}{l}-0.014 \\
(1.00)\end{array}$ \\
\hline Wife's age & $\begin{array}{l}0.056^{*} \\
(2.25)\end{array}$ & $\begin{array}{l}0.054 * \\
(2.09)\end{array}$ & $\begin{array}{l}0.053^{*} \\
(2.03)\end{array}$ & $\begin{array}{l}0.057^{*} \\
(2.32)\end{array}$ & $\begin{array}{l}0.051 * \\
(2.04)\end{array}$ \\
\hline Wife's occupation - agri. wage labourer & . & . & $\begin{array}{c}-0.285^{*} \\
(2.11)\end{array}$ & $\begin{array}{c}-0.294 * \\
(2.19)\end{array}$ & $\begin{array}{c}-0.240^{*} \\
(1.68)\end{array}$ \\
\hline Wife's occupation - agri. self-employed & . & . & $\begin{array}{l}-0.069 \\
(0.39)\end{array}$ & $\begin{array}{l}-0.066 \\
(0.39)\end{array}$ & $\begin{array}{c}-0.042 \\
(0.23)\end{array}$ \\
\hline Wife's occupation - non-agricultural & . & . & $\begin{array}{l}-0.122 \\
(0.70)\end{array}$ & $\begin{array}{l}-0.118 \\
(0.71)\end{array}$ & $\begin{array}{l}-0.109 \\
(0.60)\end{array}$ \\
\hline Wife engaged in paid work outside home & $\begin{array}{l}-0.126 \\
(1.30)\end{array}$ & $\begin{array}{c}-0.223^{*} \\
(1.95)\end{array}$ & . & . & . \\
\hline Wife owns house & $\begin{array}{c}-0.364^{*} \\
(2.14)\end{array}$ & $\begin{array}{c}-0.343 * \\
(2.02)\end{array}$ & $\begin{array}{c}-0.349 * \\
(2.04)\end{array}$ & $\begin{array}{c}-0.335^{*} \\
(2.01)\end{array}$ & $\begin{array}{c}-0.331 * \\
(1.86)\end{array}$ \\
\hline Number of male children & . & . & & $\begin{array}{l}-0.065 \\
(1.36)\end{array}$ & $\begin{array}{l}-0.072 \\
(1.39)\end{array}$ \\
\hline Number of female children & . & . & & $\begin{array}{l}0.028 \\
(0.63)\end{array}$ & $\begin{array}{l}0.023 \\
(0.50)\end{array}$ \\
\hline Nuclear family & . & . & & $\begin{array}{l}0.102 \\
(0.85)\end{array}$ & $\begin{array}{l}0.056 \\
(0.46)\end{array}$ \\
\hline Hindu - other backward castes $=1$ & . & . & & . & $\begin{array}{l}0.152 \\
(1.08)\end{array}$ \\
\hline Hindu - scheduled caste $=1$ & . & . & & . & $\begin{array}{l}0.079 \\
(0.49)\end{array}$ \\
\hline Muslim $=1$ & . & . & & . & $\begin{array}{l}0.327 \\
(1.64)\end{array}$ \\
\hline $\begin{array}{l}N \\
\text { Pseudo } R^{2}\end{array}$ & $\begin{array}{c}155 \\
0.201\end{array}$ & $\begin{array}{c}155 \\
0.227\end{array}$ & $\begin{array}{c}155 \\
0.233\end{array}$ & $\begin{array}{l}155 \\
0.25\end{array}$ & $\begin{array}{c}155 \\
0.268\end{array}$ \\
\hline
\end{tabular}

Notes: The t-statistics are based on heteroscedasticity consistent standard errors. * Statistically significant at, at least the 10 percent level. 
Table 9

Probability of Experiencing Violence and Working - Instrumental Variable Probit and Bivariate Probit Estimates

(Absolute value of T-statistic)

\begin{tabular}{|c|c|c|c|c|c|c|}
\hline Variable & $\begin{array}{l}\text { Marginal } \\
\text { Effects } \\
\text { Working } \\
\text { Bivariate } \\
\text { Probit } \\
\text { (1) }\end{array}$ & $\begin{array}{l}\text { Marginal } \\
\text { Effects } \\
\text { Violence } \\
\text { Bivariate } \\
\text { Probit } \\
\text { (2) }\end{array}$ & $\begin{array}{l}\text { Marginal } \\
\text { Effects } \\
\text { Working } \\
\text { Bivariate } \\
\text { Probit } \\
\text { (3) }\end{array}$ & $\begin{array}{c}\text { Marginal } \\
\text { Effects } \\
\text { Violence } \\
\text { Bivariate } \\
\text { Probit } \\
\text { (4) }\end{array}$ & $\begin{array}{l}\text { Marginal } \\
\text { Effects } \\
\text { Working } \\
\text { IV } \\
\\
(5)\end{array}$ & $\begin{array}{l}\text { Marginal } \\
\text { Effect } \\
\text { Violence } \\
\text { IV } \\
\\
(6)\end{array}$ \\
\hline Land owned by household & $\begin{array}{l}-0.005 \\
(0.52)\end{array}$ & $\begin{array}{l}-0.001 \\
(0.28)\end{array}$ & $\begin{array}{c}-0.0047 \\
(0.45)\end{array}$ & $\begin{array}{c}-0.0010 \\
(0.21)\end{array}$ & $\begin{array}{c}-0.0003 \\
(0.13)\end{array}$ & $\begin{array}{c}-0.0004 \\
(0.15)\end{array}$ \\
\hline Condition of house $-p u c c a$ & $\begin{array}{l}0.173 \\
(1.13)\end{array}$ & $\begin{array}{l}-0.154 \\
(1.42)\end{array}$ & $\begin{array}{l}0.119 \\
(0.67)\end{array}$ & $\begin{array}{l}-0.160 \\
(1.44)\end{array}$ & $\begin{array}{l}-0.023 \\
(0.28)\end{array}$ & $\begin{array}{l}-0.176 \\
(1.54)\end{array}$ \\
\hline Condition of house - kuccha-pucca & $\begin{array}{l}-0.035 \\
(0.28)\end{array}$ & $\begin{array}{l}-0.038 \\
(0.35)\end{array}$ & $\begin{array}{l}-0.018 \\
(0.14)\end{array}$ & $\begin{array}{l}-0.060 \\
(0.54)\end{array}$ & $\begin{array}{l}-0.052 \\
(0.54)\end{array}$ & $\begin{array}{l}-0.034 \\
(0.35)\end{array}$ \\
\hline Amount of gold in household & $\begin{array}{l}0.001 \\
(0.25)\end{array}$ & $\begin{array}{l}0.002 \\
(0.41)\end{array}$ & $\begin{array}{l}0.0014 \\
(0.26)\end{array}$ & $\begin{array}{l}0.002 \\
(0.38)\end{array}$ & $\begin{array}{l}0.0007 \\
(0.14)\end{array}$ & $\begin{array}{l}0.001 \\
(0.37)\end{array}$ \\
\hline Husband's education & $\begin{array}{c}-0.021 * \\
(1.85)\end{array}$ & $\begin{array}{c}-0.033^{*} \\
(3.27)\end{array}$ & $\begin{array}{c}-0.038^{*} \\
(3.16)\end{array}$ & $\begin{array}{c}-0.032 * \\
(3.14)\end{array}$ & $\begin{array}{c}-0.016^{*} \\
(1.91)\end{array}$ & $\begin{array}{c}-0.031^{*} \\
(2.84)\end{array}$ \\
\hline Husband's age & $\begin{array}{l}0.003 \\
(0.13)\end{array}$ & $\begin{array}{l}-0.016 \\
(0.95)\end{array}$ & $\begin{array}{l}-0.010 \\
(0.46)\end{array}$ & $\begin{array}{l}-0.015 \\
(0.91)\end{array}$ & $\begin{array}{c}-0.0001 \\
(0.01)\end{array}$ & $\begin{array}{c}-0.018 \\
(1.00)\end{array}$ \\
\hline Husband's occupation - agri. wage labourer & $\begin{array}{l}0.63^{*} \\
(7.42)\end{array}$ & $\begin{array}{l}0.295^{*} \\
(2.78)\end{array}$ & $\begin{array}{l}0.606^{*} \\
(5.73)\end{array}$ & $\begin{array}{c}0.271^{*} \\
(2.47)\end{array}$ & $\begin{array}{l}0.442 * \\
(3.90)\end{array}$ & $\begin{array}{l}0.249 \\
(1.12)\end{array}$ \\
\hline Husband's occupation - agri. self-employed & $\begin{array}{c}-0.282^{*} \\
(1.77)\end{array}$ & $\begin{array}{c}-0.389^{*} \\
(3.62)\end{array}$ & $\begin{array}{l}-0.244 \\
(1.52)\end{array}$ & $\begin{array}{c}-0.395^{*} \\
(3.71)\end{array}$ & $\begin{array}{c}-0.168^{*} \\
(1.82)\end{array}$ & $\begin{array}{c}-0.369^{*} \\
(2.74)\end{array}$ \\
\hline Wife's education & $\begin{array}{l}0.021 \\
(1.34)\end{array}$ & $\begin{array}{r}-0.004 \\
(0.27)\end{array}$ & $\begin{array}{c}0.040^{*} \\
(2.22)\end{array}$ & $\begin{array}{l}-0.004 \\
(0.33)\end{array}$ & $\begin{array}{l}0.018 \\
(1.60)\end{array}$ & $\begin{array}{r}-0.004 \\
(0.32)\end{array}$ \\
\hline Wife's age & $\begin{array}{l}0.006 \\
(0.23)\end{array}$ & $\begin{array}{l}0.043^{*} \\
(2.21)\end{array}$ & $\begin{array}{l}0.040 \\
(1.58)\end{array}$ & $\begin{array}{l}0.042^{*} \\
(2.14)\end{array}$ & $\begin{array}{l}0.014 \\
(1.08)\end{array}$ & $\begin{array}{l}0.046^{*} \\
(2.24)\end{array}$ \\
\hline Wife works outside home & . & $\begin{array}{l}-0.64^{*} \\
(11.79)\end{array}$ & & $\begin{array}{l}-0.624 * \\
(11.14)\end{array}$ & . & $\begin{array}{c}-0.623^{*} \\
(1.73)\end{array}$ \\
\hline Wife owns house & $\begin{array}{l}-0.054 \\
(0.27)\end{array}$ & $\begin{array}{l}-0.28 * \\
(2.00)\end{array}$ & $\begin{array}{r}-0.027 \\
(0.14)\end{array}$ & $\begin{array}{c}-0.286^{*} \\
(2.09)\end{array}$ & $\begin{array}{l}-0.014 \\
(0.15)\end{array}$ & $\begin{array}{c}-0.270^{*} \\
(2.40)\end{array}$ \\
\hline Number of male children & $\begin{array}{l}0.092^{*} \\
(2.09)\end{array}$ & . & $\begin{array}{l}0.036 \\
(0.71)\end{array}$ & . & $\begin{array}{l}0.013 \\
(0.45)\end{array}$ & . \\
\hline Number of female children & $\begin{array}{l}-0.004 \\
(0.12)\end{array}$ & . & $\begin{array}{r}-0.006 \\
(0.18)\end{array}$ & $\cdot$ & $\begin{array}{l}0.005 \\
(0.19)\end{array}$ & . \\
\hline Nuclear family & $\begin{array}{l}-0.021 \\
(0.19)\end{array}$ & . & $\begin{array}{r}-0.089 \\
(0.52)\end{array}$ & . & $\begin{array}{l}0.014 \\
(0.17)\end{array}$ & . \\
\hline Hindu - other backward castes $=1$ & . & . & $\begin{array}{l}0.025 \\
(0.14)\end{array}$ & . & $\begin{array}{c}0.046 \\
(0.39)\end{array}$ & . \\
\hline Hindu - scheduled caste $=1$ & . & . & $\begin{array}{c}0.374^{*} \\
(2.01)\end{array}$ & . & $\begin{array}{c}0.266^{*} \\
(2.18)\end{array}$ & . \\
\hline Muslim $=1$ & . & . & $\begin{array}{l}-0.085 \\
(0.39)\end{array}$ & . & $\begin{array}{l}-0.027 \\
(0.19)\end{array}$ & . \\
\hline $\begin{array}{l}N \\
\text { Partial R-squared of excluded instruments } \\
\text { F-test of excluded instruments ( } p \text {-value) } \\
\text { Overidentification test (p-value) }\end{array}$ & \multicolumn{2}{|c|}{$\begin{array}{c}155 \\
\cdot \\
\cdot\end{array}$} & \multicolumn{2}{|c|}{$\begin{array}{c}155 \\
\cdot \\
.\end{array}$} & \multicolumn{2}{|c|}{$\begin{array}{c}155 \\
0.083 \\
0.065 \\
0.419 \\
\end{array}$} \\
\hline
\end{tabular}

Notes: * Statistically significant at, at least the 10 percent level. 
Table A1: Additional Sensitivity Analysis

(Absolute value of T-statistic)

\begin{tabular}{|c|c|c|c|c|c|}
\hline Variable & $\begin{array}{c}\text { Marginal } \\
\text { Effects } \\
\text { Probit } \\
(1)^{\mathrm{a}}\end{array}$ & $\begin{array}{l}\text { Marginal } \\
\text { Effects } \\
\text { Probit } \\
\text { (2) }\end{array}$ & $\begin{array}{l}\text { Marginal } \\
\text { Effects } \\
\text { Probit } \\
\text { (3) }\end{array}$ & $\begin{array}{c}\text { Marginal Effects } \\
\text { Working } \\
\text { IV } \\
\text { (4) }\end{array}$ & $\begin{array}{c}\text { Marginal Effects } \\
\text { Violence } \\
\text { IV } \\
\text { (5) }\end{array}$ \\
\hline Land owned by household & $\begin{array}{c}-0.0011 \\
(0.31)\end{array}$ & $\begin{array}{l}0.002 \\
(0.46)\end{array}$ & $\begin{array}{c}-0.008^{*} \\
(1.75)\end{array}$ & $\begin{array}{l}-0.0004 \\
(0.17)\end{array}$ & $\begin{array}{c}-0.0003 \\
(0.15)\end{array}$ \\
\hline Condition of house $-p u c c a$ & $\begin{array}{l}-0.206 \\
(1.63)\end{array}$ & $\begin{array}{l}-0.199 \\
(1.55)\end{array}$ & $\begin{array}{l}-0.078 \\
(0.53)\end{array}$ & $\begin{array}{l}-0.028 \\
(0.32)\end{array}$ & $\begin{array}{l}-0.177 \\
(1.56)\end{array}$ \\
\hline Condition of house - kuccha-pucca & $\begin{array}{l}0.013 \\
(0.11)\end{array}$ & $\begin{array}{l}0.014 \\
(0.11)\end{array}$ & $\begin{array}{l}0.079 \\
(0.51)\end{array}$ & $\begin{array}{l}-0.058 \\
(0.63)\end{array}$ & $\begin{array}{r}-0.032 \\
(0.33)\end{array}$ \\
\hline Amount of gold in household & $\begin{array}{l}0.003 \\
(0.59)\end{array}$ & $\begin{array}{l}0.002 \\
(0.38)\end{array}$ & $\begin{array}{l}0.008^{*} \\
(1.70)\end{array}$ & $\begin{array}{l}0.0005 \\
(0.10)\end{array}$ & $\begin{array}{l}0.001 \\
(0.38)\end{array}$ \\
\hline Husband's education & $\begin{array}{c}-0.029 * \\
(2.68)\end{array}$ & $\begin{array}{l}-0.029^{*} \\
(2.69)\end{array}$ & $\begin{array}{c}-0.038^{*} \\
(2.98)\end{array}$ & $\begin{array}{l}-0.017^{*} \\
(2.04)\end{array}$ & $\begin{array}{c}-0.030^{*} \\
(2.83)\end{array}$ \\
\hline Husband's age & $\begin{array}{l}-0.024 \\
(1.10)\end{array}$ & $\begin{array}{l}-0.027 \\
(1.19)\end{array}$ & $\begin{array}{l}-0.026 \\
(1.16)\end{array}$ & $\begin{array}{l}0.0001 \\
(0.01)\end{array}$ & $\begin{array}{l}-0.018 \\
(1.01)\end{array}$ \\
\hline Husband's occupation - agri. wage labourer & $\begin{array}{l}0.021 \\
(0.15)\end{array}$ & $\begin{array}{l}0.015 \\
(0.10)\end{array}$ & $\begin{array}{l}0.124 \\
(0.76)\end{array}$ & $\begin{array}{l}0.435^{*} \\
(3.92)\end{array}$ & $\begin{array}{l}0.229 \\
(1.04)\end{array}$ \\
\hline Husband's occupation - agri. self-employed & $\begin{array}{c}-0.321^{*} \\
(1.77)\end{array}$ & $\begin{array}{c}-0.310^{*} \\
(1.71)\end{array}$ & $\begin{array}{l}-0.196 \\
(0.76)\end{array}$ & $\begin{array}{l}-0.174 * \\
(1.91)\end{array}$ & $\begin{array}{c}-0.362^{*} \\
(2.70)\end{array}$ \\
\hline Wife's education & $\begin{array}{l}-0.022 \\
(1.58)\end{array}$ & $\begin{array}{l}-0.022 \\
(1.55)\end{array}$ & $\begin{array}{l}-0.014 \\
(0.86)\end{array}$ & $\begin{array}{l}0.018 \\
(1.61)\end{array}$ & $\begin{array}{l}-0.004 \\
(0.36)\end{array}$ \\
\hline Wife's age & $\begin{array}{c}0.053^{*} \\
(2.03)\end{array}$ & $\begin{array}{l}0.055^{*} \\
(2.11)\end{array}$ & $\begin{array}{l}0.063^{*} \\
(2.53)\end{array}$ & $\begin{array}{l}0.016 \\
(1.25)\end{array}$ & $\begin{array}{l}0.046^{*} \\
(2.25)\end{array}$ \\
\hline Wife's occupation - agri. wage labourer & $\begin{array}{c}-0.285^{*} \\
(2.11)\end{array}$ & $\begin{array}{c}-0.405^{*} \\
(2.43)\end{array}$ & $\begin{array}{c}-0.353^{*} \\
(2.15)\end{array}$ & . & $\begin{array}{l}-0.590 \\
(1.63)\end{array}$ \\
\hline Wife's occupation - agri. self-employed & $\begin{array}{l}-0.069 \\
(0.39)\end{array}$ & $\begin{array}{l}-0.098 \\
(0.57)\end{array}$ & $\begin{array}{l}-0.178 \\
(0.95)\end{array}$ & . & $\begin{array}{c}-0.270^{*} \\
(2.41)\end{array}$ \\
\hline Wife's occupation - non-agricultural & $\begin{array}{l}-0.122 \\
(0.70)\end{array}$ & $\begin{array}{l}-0.381 \\
(1.53)\end{array}$ & $\begin{array}{l}-0.129 \\
(0.63)\end{array}$ & & (2) \\
\hline Wife owns house & $\begin{array}{c}-0.349^{*} \\
(2.04)\end{array}$ & $\begin{array}{l}-0.360 \\
(2.05)\end{array}$ & $\begin{array}{c}-0.381 * \\
(1.73)\end{array}$ & $\begin{array}{l}-0.009 \\
(0.11)\end{array}$ & . \\
\hline Husband's annual income*1000 & . & $\begin{array}{l}-0.003 \\
(0.89)\end{array}$ & . & . & . \\
\hline Wife's annual income*1000 & . & $\begin{array}{l}0.0254 \\
(1.44)\end{array}$ & . & . & . \\
\hline Husband's consumes alcohol & . & 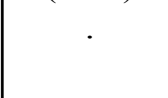 & $\begin{array}{l}0.294^{*} \\
(2.15)\end{array}$ & . & . \\
\hline $\begin{array}{l}\text { Hindu - other backward castes }=1 \\
\text { Hindu - scheduled caste }=1 \\
\text { Muslim }=1\end{array}$ & . & . & . & $\begin{array}{l}0.047 \\
(0.40) \\
0.276^{*} \\
(2.24) \\
-0.013 \\
(0.09) \\
\end{array}$ & . \\
\hline $\begin{array}{l}N \\
\text { Pseudo } R^{2} \\
\text { Partial R-squared of excluded instruments } \\
\text { F-Test of excluded instruments ( } p \text {-value) } \\
\text { Overidentification test (p-value) }\end{array}$ & $\begin{array}{c}155 \\
0.233\end{array}$ & $\begin{array}{c}155 \\
0.243\end{array}$ & $\begin{array}{c}125 \\
0.288\end{array}$ & \multicolumn{2}{|c|}{$\begin{array}{c}155 \\
\cdot \\
0.082 \\
0.0085 \\
0.3030 \\
\end{array}$} \\
\hline
\end{tabular}

Notes: The t-statistics are based on heteroscedasticity consistent standard errors $*$ Statistically significant at, at least the 10 percent level. ${ }^{a}$ This is the same specification reported as specification 3 in Table 8 . 